\title{
Islamic Civil Society and Conflict Resolution Muhammadiyah's Challenges Towards The Dynamics of Malaysia-Indonesia Relationship
}

\author{
Muhammad Zahrul Anam \\ Jurusan IImu Hubungan Internasional, Fakultas IImu Sosial IImu Politik, Universitas Muhammadiyah Yogyakarta \\ Ringroad Barat Tamantirto, Kasihan, Bantul 55183 \\ Email: zahrul@umy.ac.id
}

\begin{abstract}
Abstrak
Tulisan ini menjelaskan mengapa Muhammadiyah sebagai gerakan Islam terbesar di Indonesia terlihat "diam" dalam menangani ketegangan antara Indonesia dan Malaysia. Ada beberapa faktor potensial penyebab konflik: perbatasan, budaya, dan pekerja migran. Selain itu, pekerja migran dan perbatasan dapat menimbulkan korban jiwa. Dalam hal ini, Muhammadiyah dengan keanggotaan yang berkembang dan luas, struktur organisasi dan jaringan internasional harus mengambil peran utama dalam resolusi konflik. Namun, kapasitas resolusi konflik dalam merespon ketegangan menjadi masalah bagi Muhammadiyah. Tulisan ini menggunakan teori Becky Nesbin mengenai peranan LSM Internasional dan LSM dalam tiga tingkatan konflik, yakni konflik laten, peningkatan permusuhan, dan perdamaian. Tingkat pertama dan kedua membutuhkan advokasi dan tingkat ketiga memberdayakan orang-orang untuk mengurangi konflik yang lebih lanjut. Untuk meningkatkan kapasitas, Muhammadiyah perlu bertransformasi dan menyiapkan langkah strategis. Selain itu, juga dibutuhkan untuk meningkatkan kerjasaman, penelitian, dan kerjasama dengan pemimpin dan komunitas internasional.

Kata Kunci: Muhammadiyah, peradaban masyarakat muslim, resolusi konflik, NGO
\end{abstract}

\begin{abstract}
This paper explains why Muhammadiyah, as the biggest Islamic movement in Indonesia, seems to be "silent" in dealing with tension between Indonesia and Malaysia. There are several potential factors of conflict: boundary, culture and migrant workers. Furthermore, migrant worker and boundary may cause casualties. In this regard, Muhammadiyah with its developed and extended membership, organizational structure and international network should take major part in the conflict resolution. However, conflict resolution capacity to respond the tension is becoming problem for Muhammadiyah itself. This paper uses a theory put forward by Becky Nesbitt on the role of INGOs and NGOs in three levels of conflict, namely, latent conflict, escalating hostilities conflict and peace building. The first and second level of conflict require advocacy and the third level employs people empowerment in reducing further conflict. To enhance the capacity, Muhammadiyah needs to transform and formulate a strategic action. In addition, it also needs to improve cooperation, research and network with the international leader and community. Keywords: Muhammadiyah, Islamic Civil Society, Conflict Resolution, NGO
\end{abstract}

\section{INTRODUCTION}

Social and political instability problem faced by ASEAN members tend to weaken the regional ties. Following this, their foreign investors will withdraw the investment and move it to China. ${ }^{1}$ In response to this issue, ASEAN Foreign Minister Meeting on July 2001, Hanoi, agreed to set up the Supreme Commit- tee to mediate, investigate and overcome the conflicts taking place in Southeast Asian region such as South Chinese Sea and other boundary conflicts ${ }^{2}$.Although the existence of the Supreme Committee is necessary, the most important actor of conflict is the state or group. According to the International Relations 
references recently, the non-state actors,such as Multinational Corporations (MNCs), International Governmental Organizations (IGOs) and International NonGovernmental Organizations (INGOs) also transnational groups, play a significantly role in the international issues like world peace, refugees, climate change, human trafficking, Human Right, culture and tourism ${ }^{3}$. Therefore, it should be taken into account since it deals with the conflict resolution.

In ASEAN, in spite of having more similarities than differences in language, religion, and ethnicity,Malaysia and Indonesia are prone to conflicts in terms of political and economic areas such asboundaries ${ }^{4}$ and migrant workers.As quoted by Anak Agung Banyu Perwita from the Indonesian Defense White Paper 2003, Malaysia is one of ten neighboring countries having border problem with Indonesia and other nine countries, namely, Singapore, Australia, Philippine, Papua Nugini, Vietnam, India, Thailand, Timor Leste and the Republic of Pulau. ${ }^{5}$ Without serious concern, Indonesian's security and sovereignty will be in the critical circumstances due to possible annexation of the neighboring countries ${ }^{6}$. Given the ignoring territorial difficulties, it isclearly understandable why Ambalat as well as Sipadan and Ligitan Island conflict occurred between Malaysia and Indonesia.

Meanwhile, Indonesian migrant labor working in Malaysiais particulary an essential matter as it is discussed in the issue ofglobal people mobility.Labor migration is affected by two structural factors. The first factor relates to "wage zone" or "wage differential" because differential level of wages and social benefits and thus standards of living, can have a major impact on migration between countries. The second factor is concerned with the demand for labor and the levels of unemployment. The combination of divergent wage and unemployment levels in different countries creates a powerful impetus for migration?. More Indonesian labors living in Malaysia are interested in high salary than knowledge improvement and skill enrichment. The other reason why they have been in Malaysia is the Indonesian unemployment rates.

Since economic turmoil in 1997, the Indonesian economy has increased slowly while the poverty has decreased gradually. In addition, the birth population has been likely to rise up. As a result, the huge unskilled rural people depart to the big cities in Indonesia to seek alternative job. Staying at home and being a farmer or fisherman is not the best way anymore for income generating of villagers. Farmers have no much budget to pay expenses in cost of production and operation. They, then, prefer to sell their land and be monthly-paid farmer. Moreover, Free Trade Agreement ratified by the government requires the state to withdraw subsidy and reduce tariff for imported good and services.It assumes that the cheapest product and the most efficient services will monopolize marketplace, whereas Indonesian product with high production cost will be hard to compete. For instance, a number of food supplies come from neighbors and China such as rice, powder and corn. The food price of local production is more expensive than the imported goods. Consequently, despite their insufficient knowledge, the majority of people attempt to change their job in manufacture industry. In doing so, they go to business areas located both in home and abroad. Malaysia becomes a favorite destination to work in.

Like Saudi Arabia, a number of Indonesian female labors working for Malaysian family at homeare suffered from bullying and violence like sexual abuse and torture. Indeed, they have contributed indirectly to Malaysian productivity ${ }^{8}$ at the family or community level.The question why this violence arises is probably because of gap between an expectation and reality. Malaysian families paying the agent find that their workers are unskillful people. It, then, triggers misunderstanding and misperception each other. Furthermore, they also are victims of human trafficking practiced by the international syndicate. Shortly, they need the government assistance in legal protection and training program in cultural matters and technical skill. These efforts are urgent to avoid latent conflict among societies. Similarly, Malaysiangovernment should actively supervise and warn the employers for respecting human right. This violence causes critical injuries of Indonesian female workers. 
To solve boundary and migrant disputes comprehensively,formal meeting between both governments is no longer enough. They represent their own state's economic interest as well as the citizen. For instance, to boost productivity and economic competitiveness, Malaysia will invite the great number of migrant labors who are ready at the first time with low income. Obviously, the economic interest and its citizen is the highest priority. Similarly, falling the rates of unemployment is Indonesian government's top agenda so that it encourages people to go abroad to work. Without strong commitment to implement the treaty, workplace violence remains unchanged. In contrast,informal meeting among communities is likely to be neutral endeavor from the political interest. Thus, it is a prospective way to precede peaceful negotiation both sides.

In politics and democracy, a civil society is third power after political party and market in which the people may control the decision-making process and evaluate its implementation. For instance, Muhammadiyah, the largest Islamic movement in Indonesia, proposed the presidency succession in 1998.It was a memorable experience for the Indonesian people when Soeharto, 30-year Indonesian President, resigned from his office because of People Power movement called Reform Movement (Reformasi). During Soeharto's administration, there was a pseudo democracy that the government strictly limited the freedom of expression and press. By Anti Subversion Bill, it allowed to capture anyone who was suspected to threat national security without any jurisdiction process. Meanwhile, the rate of economic growth wasabout $7 \%$ per year. National security is themain component to support the economy. It is evident that Soeharto allocated much more money to purchase the weapons in the National Budget Plan. Obviously, at that time, Indonesian arm force was very strong. It is not only for defense purposes but also for Soeharto's power sustainability. He created "Dwi Fungsi ABRI" (Arm Forces Dual Function), meaning that arm forces havedouble functions: politics and security. For this reason, he appointed the elite arm force to be governors and mayors at local governance. As a result, they used repressive political communication to the public. It is widely believed that such a situation was a dominant factor to flourish the corruption, collusion and nepotism. This condition destroyed the Indonesian fundamental economy.

Since Indonesian reform, Indonesian political system has changed to be more democratic. First, people are free to establish the political party as long as it meets all requirements. Second, president and vice president will be voted directly. Third, there is bicameral system: House of Representative and Regional Representative (Dewan Perwakilan Daerah). Fourth, it is very difficult to impeach president and the president has two-year maximum period in the office. Amien Rais, one of the prominent figures of Muhammadiyah, contributed this political change. He also encourages the parliament members of the Partai Amanat Nasional (the National Mandate Party) to continue his reform agenda. Two ways communication of Muhammadiyah and political parties will achieve the positive impact for future politics.

Relatingto fluctuating relationship betweenMalaysia and Indonesia, Muhammadiyah as the Islamic civil society of Indonesia has opportunity to enhance cooperation among societies and reconcile the conflict possibilities. This paper will be divided into three parts. The first part will highlight the Malaysia-Indonesia Relations conflict in the historical perspective. It discusses the time frame of cooperation and confrontation between them. The second part of this research willdescribeCivil Societyand Conflict Resolution theoretical framework. Finally, the research will explain how Muhammadiyah should become a strategic institution in building harmonic relationship between Malaysia and Indonesia and what challenges it faces.

\section{ANAYSIS}

\section{HISTORY OF MALAYSIA-INDONESIA RELATIONS}

In 1960s, conflict arose between Malaysia and Indonesia. Soekarno, the first President of Indonesia, had met Tengku Abdul Rahman, the Prime Minister 
of Malaysia, to discuss the refusal ofthe Britishs' proposal for the Federation of Malaya from $13^{\text {th }}$ to $1^{\text {st }}$ June 1963. Soekarno then signed the proposal with the British government on July $9^{\text {th }}, 1963$ in London.He agreed to the British's plan to establish the Federation of Malaya on August 31 ${ }^{\text {st }} 1963 .{ }^{9}$

Indonesia and Philippine would accept Federal of Malaysia as long as the majority of Malaysian citizen voted in referendum. To do so, between July and August 1963, there was a Summit of tripartite consisting of Malaysia, Indonesia and Philippine to identify Malaysian's aspiration included in the Manila Accord. After that, UN Secretary General appointed the representativeto investigate the aspiration. However, Federation of Malaysia had officially been declared on September $16^{\text {th }}$, 1963 beforethe mission wascompleted. ${ }^{10}$

The Federation of Malaya sponsored by the United Kingdom separated the Borneo island into two groups: Sabah and Sarawak at the north belonged to Malaysia and the provinces located in the south belonged to Indonesia. According to Soekarno, this federation threatened the regional stability. Following this, he took aggressive response in the foreign policy. Soekarno announced the axis of New Emerging Force and Old Established Force that illustrated the excolonialized country and the colonialist power. Soekarno strengthened the relationship with China and its communist allies. Furthermore, he attacked the Western Blok. In 1965, Indonesia resigned from the United Nations because it accepted Malaysia as member of the Security Council. In this regard, Indonesia was internationally isolated and should fight the Indonesian Communist Party that would take over the power. ${ }^{11}$

In comparison, in the Soeharto's period, the second President of Indonesia, conflict between Malaysia and Indonesia was at minimum level. According to Zainuidin Maidin, the former Minister of Information Affairs of Malaysia, Soeharto completely solved the bilateral conflict of Malaysia-Indonesia which was started in 1960s. He and Tun Razak, the former Prime Minister of Malaysia, developed peaceful relationship. Despites harmonic relationship between Soeharto and Tun Razak,Mahatir Mohamad disagreed for Soeharto's charges of the Human Right abuse.

Maidin said that Malaysian people built the Village of Soeharto in Selangor to admire him. ${ }^{12}$

Since Soeharto's resignationin 1998, Indonesia and Malaysia relationship deteriorated due to conflicts.

There are ten cases of Malaysia and Indonesia conflict:

1. Islamic terrorism leaders came from Malaysia, namely, Dr. Azahari and Noordin M. Top. They were already killed in gunfire with the Indonesian Police.

2. Malaysia's claim on Sipadan and Ligitan islands were successfully approved by the International Court and rejected Indonesian's ownership.

3. Malaysian would like to expand its boundary by claiming the Ambalat Block that is located in the East Kalimantan. In 2005, it worsened when Malaysian Marine captured 17 Indonesian workers and ousted fisherman from the Ambalat Block.

4. Malaysia takes part in the illegal logging of Kalimantan forest. There is a route founded by the Indonesian government to smuggle the trees from Kalimantan.

5. The protection for the Indonesian workers in Malaysia is inappropriate. Thus, torture, canceled payment of salaryand deportation are worse experiences of the labor work for Malaysian. Malaysia may claim the art performance practiced by the Indonesian labors.

6. In Kalimantan, Sulawesi and Sumatera, Malaysian fisherman has disobeyed the boundary by arriving illegally in the Indonesian territory.

7. Malaysian Police hit Donald Pieter Luther, the karate judge from Indonesia on August 2007 without any reason.

8. Malaysia would like to register the copyright of the ParangBatik from Yogyakarta, the culinaryof Indonesia and its handicraft. The reason why Malaysia does so is because Indonesia had not registered them yet.

9. Malaysia claims that the Angklung, the Reog Ponorogo and Kuda Lumping belong to Malaysia. 
10. The majority of Malaysian Blog called Indonesian as the indon, the term used by Malaysian to discriminate people coming from Indonesia. ${ }^{13}$

Military presence in to solve the boundary dispute will endanger the stability of ASEAN region. It inspires other states to strengthen military device and personnel in the future. According to Rochdi Mohan Nazala, in this situation, Malaysia and Indonesia should play a significant role to ensure that the development of military posture in each country in Southeast Asia would not put regional stability in danger. ${ }^{14}$

\section{THEORETICAL FRAMEWORK OF CIVIL SOCIETY AND CONFLICT RESOLUTION}

Civil Society was originated from a movement of Latin America that opposed two repressive powers: the government and the exploitative international financial interest. In addition, it does not associate with the political party (the governance body) or the market. ${ }^{15}$ From 1980 s to 1990 s of political transition after the dismantlement of the communist block in particular, civil society was introduced by multilateral agencies as a tool for democracy assistance program ${ }^{16} \mathrm{It}$ has flourished into several non-state actors: formal organization, informal network and social movement. In the globalization era, it is part of democratic freedom of the society sharing particular interest, purpose and value ${ }^{17}$. UNDP defines civil society as:

"All associations or organizations that are private, voluntary, not-for-profit, at least partly independent or autonomous of the state and are pursuing a common interest, protecting a common value or advocating a common cause" 18

It meets conflict with the government, market or an international force in completing its mission for promoting democracy and justice. Conflict, according to Bernard Mayer, may be viewed as occurring along cognitive (perception), emotional (feeling) and behavioral (action) dimension. ${ }^{19} \mathrm{He}$ says that conflict, as a set of perceptions, is a belief or understanding that one's own needs, interests, wants or values are incompatible with someone's else.There are both objective and subjective elements to this cognitive dimension. Objective element relates to perception of the public domain such as bill or regulation of public policy. Subjective element is dealing with perception of private matter ${ }^{20}$. For instance the western lifestyle is incompatible with the eastern people philosophy of life.

He continues that conflict also involves an emotional reaction to a situation or interaction that signals a disagreement of some kind. The emotions felt might be fear, sadness, bitterness, anger, or hopelessness, or to amalgam of these. These feelings are the indicators that conflict occurs among individuals or groups. Then, conflict, seen as the behavior, consists of the actions to express the feeling, articulation of the perception and obtaining the need. The certain way of someone expression may interfere with someone else's ability to obtain her or his needs. This conflict causes something happen at someone else's expense. ${ }^{21}$

He classified five sources of conflict. The first source is the imperfect communication. Humans are very imperfect communicator. This imperfection generates conflict, whether or not there is a significant incompatibility of interest, and it almost always makes conflict harder to solve. The main problem that should be taken into consideration is how hard it is for individuals to communicate about complex matters, particularly under emotionally difficult circumstances.Conflict frequently escalates because people act on the assumption that they have communicated accurately when they have not.

The second is the emotion. Emotions are the energy that fuel conflict. They contribute to the energy, strength, courage and perseverance that allow people to participate forcefully in conflict. However, they are also a key to deescalating it. Many emotions can prevent, moderate, or control conflict. Although emotional reaction of conflict is spontaneous, it should not release it so much to escalate the conflict. The important point is how to express an adequate emotional response in conflict. The third source of 
conflict is the value. Values are the beliefs each society has about what is important, what distinguishes right from wrong and good from evil, and what principles should govern how to lead the life. People who define themselves in part by their core beliefs defend totally when their values are under attack. In comparison, it is a source of commonality and a restraint on conflict escalation. Normally, the disputants can find the "meeting point" on which they share values, and they often have values about interpersonal relations that support collaborative effort.

The fourth source of conflictis structure. The elements of a structure may consist of resources, decision-making procedures, time constraints, communication procedures and physical settings. Other structural elements that affect conflict include proximity of the disputants, distribution of resources, access to information, legal parameters, organizational structure and political pressure. The example is voting. It is used to resolve differences about an issue; the issue tends to be polarized and constructive communication can become difficult. These structural realities can be changed through a conflict resolution process, whereas it is very hard. Fifth is history. Conflict cannot be separated from its historical context. The history of conflict tells about the actors of conflict, issues and systems. It provides the momentum for the development of conflict.Furthermore, it affects other sources of conflict: values, communication style, emotional reaction and the structure that people operate. $^{22}$

In term of the international relations discourses, conflict, as quoted by Surwandono from Jhon Spanier, are divided into two types: the first is highpolitics conflict that consist of security, ideology issues and competition among countries taking place globally, regionally and nationally. This kind of conflict employs "zero-sum" game in which the absolute winner and loser is clearly shown. The second type is low-politics that consist of economic, social and cultural issues, technology and environment. This second type of conflict employs "non-zero-sum" game in which the disputants compromise each other to find out the best solution. So, there is no absolute winner or loser in the non-zero-sum game. ${ }^{23}$

There is variety of $\mathrm{NGOs}$ role in conflict resolution. It can be involved in giving basic services refugee camps, providing trauma counseling for victims, providing food and medical services or facilitating dialogue for warring factions. ${ }^{24}$ Further, discussing NGOs' involvement in conflict resolution, Becky Nesbitt examines two theories to see its role: the first is a model of peace process presented by Jhon Lederach and the second is Kalyspso Nicolaïdis strategic framework of international preventive action in situations of conflict ${ }^{25}$.

According to Lederach, there are three levels of actors in the peace building process and each level of actors engages in different peace building task. The first level is top leader such as military, religious and political leaders who have high visibility. They engage in high-level negotiation, mediation and ceasefire. The second level is the middle range leader such as ethnic and religious leaders, leaders of humanitarian NGOs, scholars and other respected leaders. They provide problem-solving workshop, training in conflict resolution, peace commission and insider-partial team. Lastly, the third level is the grassroots leader such aslocal leader, indigenous NGOs, community developer and local health official. They emphasize on local peace commission, grassroots training, prejudice reduction and the psychosocial work in post-war trauma. He argues that the true peace building is the social, economic, socio-psychological and spiritual changes in lives of the people involved. Lederachs' theory does not analyze the preventive action whereas Kalyspso Nicolaïdis does.

Kalyspso Nicolaïdis's strategic framework delivers the pattern of preventive action of the international community that can occur during the various stage of conflict. She divides into a timeline with three main stages. The first stage is a latent conflict that needs early diplomacy to prevent the eruption of conflict. The second stage is hostile explosion that requires late preventive diplomacy to prevent further escalation of conflict. The final stage is the post-conflict peace 
building and this stage continuing preventive diplomacy is required to prevent a recurrence of the conflict. She formulates a typology of international preventive diplomacy. There are two kinds of preventive action: the first is based on method (hands-on or hands-off) and the second is based on the scope (ad hoc or systemic). Hands-off methods would be constructed by incentives or signaling actions such as threats. Hands-on method includes capacity building and addressing root causes of conflict. The systemic actions are more long-term strategies embedded in norm and institutions while ad hoc actions are for short-term period. She, then, delivers four kinds of possibility action as method-scope combination: coercive diplomacy (hands-off, ad hoc), institutional inducement (hands-off, systemic), cooperative management (hands-on, ad hoc) and systemic transformation (hands-on, systemic). ${ }^{26}$

Becky Nesbitt explains more about NGOs activities dealing with three stages of conflict: latent conflict, escalating hostilities and peace-building endeavor. During in the latent conflict, the primary work of NGOs is advocacy. In this regard, NGOs or INGOs have a task to observe the local populace and the relations among various religious, ethnic and political group. This observation would like to objectively notice what is exactly going on. It is very useful for NGOs working with grassroots people in warning national and international leaders before the conflict breaks out.

Then, in escalating hostilities stage, it remains providing advocacy. For INGOs in cooperation with media, it collects data and evidences about violence and abuse to drive the international community action. In term of advocacy, NGOs also mediates and encourages leaders to engage in peace negotiation or ceasefire. In addition, NGOs provides assistance in food supply, medicines and refugee camps. Finally, for peace-building stage, it empowers people and helps them transform the attitudes and institutions in order to help reduce tension and prevent further violence conflict. $^{27}$

\section{STRATEGIC POLITICAL POSITION AND CHALLENGE OF MUHAMMADIYAH IN CONFLICT RESOLUTION}

In 1912, Muhammadiyah founded by K.H.Ahmad Dahlan was the first well-organized Islamic movement of Indonesia. Inspired by the Islamic revivalists from Middle East, he initiated the independent Islamic organization to reform the Javanese Muslims from syncretism ${ }^{28}$ practice, poor health and education access and colonialism. At the same time, according to Alfian, Muhammadiyah plays three main roles: religious reform, social and cultural changing and political forces. ${ }^{29}$

For Muhammadiyah, purifying the Islamic teaching is crucial issue. It does not mean every Muslim should imitate literally the Arabic custom of what The Last Prophet did without any rational thinking. It announces the Tajdid concept that means using Quran and The Last Prophet's tradition as a guideline for worship and interpreting them by critical method to figure out the answer dealing with contemporary problem. It welcomes a new invasion in modern science and technology as long as it is in line with the Islamic principle. At the first time, the idea of purification is rejected by majority of Javanese Muslims. However, Muhammadiyah is successful to convince the people through dialogue and to proof the modern Islam.

Health and education are the prioritiesin building a qualified and skillful human resource.During colonialism period, the citizens divided into three levels: the highest level was Europeans or Dutch and Indonesian noble. The middle level was Chinese and the third level was Indonesian (native). Western education is for expatriates, Chinese, the Indonesian noble and a few people of third level spending much money to pay the tuition. Like the education, the Indonesian Muslims in particular had a little opportunity to use the hospital owned by the Dutch. As a result, Muhammadiyah has started to provide as modern education system as the Western style with the additional religious subject. Nowdays, Muhammadiyah has hundreds of kindergartens, schools from elementary to junior and high school, vocational school and univer- 
sities as well as colleges. In addition, it has hundreds hospitals and house of health service.

Muhammadiyah is a significant political force and concerns on fighting colonialism in particular. Alfian said that there are two important reasons why Muhammadiyah has been seen as a major political entity of Indonesia. First, It refers to

Muhammadiyah's point of view about Islam-state unity. Islam and state cannot be separated like the Western secularism. Second, it is an interest group that has encouragedthe political Islam in Indonesia. In 1927, after The Indonesian Communist Party failed to take over the power, Muhammadiyah succeeded to gain huge members in Minangkabau. It, then, fought against the Dutch openly. After that, in 1950s, it was an influential group in political completion between the national party represented by the Partai Nasional Indonesia (the Indonesian National Party), the Partai Komunis Indonesia (the Indonesian Communist Party) and the Islamic Parties (Masyumi and the Nadhatul Ulama). ${ }^{30}$

In 1990s, emerging new wave of democracy in Indonesia post New Order era was a result of the critical thought and action of Muhammadiyah. From 1960s to 1990s, the Soeharto regime seemed to be dictator leader. Freedom of expression and press was strictly ignored. Nepotism and collusion flourished because of minimum control of the government. Soeharto had the "ultimate power" like a king without check and balances from the public representative. Despite being dictator, political stability leads Indonesia to reach the economic growth $7 \%$ per year. Unfortunately, the corruption was growing rapidly. Hence, Muhammadiyah moved forward to eradicate those political deviances.Overall, Muhammadiyah as the Islamic civil society movement has a strategic position to be a pressure group to deliver the public interest and to control the process of democracy.

Its important position is an advantage for Muhammadiyahto have active role in conflict resolution between Indonesia and Malaysia. Furthermore, its social capital has extended the membership, international network and institutional structure. Its wing organizations are the stations to attract the new members consisting of women, students and youths. It also develops successfully the international branches in Egypt, Malaysia and the United States of America. This advance of its membership and branches would be positive impact for enlarging the institutional structure. Although Muhammadiyah center is located in Indonesia, its potentials are the indicators that Muhammadiyah would be close to the International Non-government Organization operated in different states and followed by the international member. Therefore, it should encourage and initiate the peaceful relationship before, during and after the conflict. Muhammadiyah has experience in humanitarian aid for the recovery agenda of both disaster and conflict victims. In doing this, it develops MDMC (Muhammadiyah Disaster Management Center) that prepares for tackling casualties of natural disaster and conflict. In spite of being invited by MILF to mediate with the government of Philippine, Muhammadiyah's track record in resolving conflict is still in moderate level because of its minimum peace paradigm.

Discussing Muhammadiyah contribution in Malaysia-Indonesia tension of migrant workers, culture and border, it, as mentioned by Becky Nesbitt, delivers advocacy in two levels of conflict: latent conflict and escalating hostilities stage. At the latent of conflict, Muhammadiyah in cooperation with local community should observe the changing relations process among believers, ethnic group and political party including regulation as well. This observation aims to understand the cause of possible conflict and warn national and international leader before conflict occurs.

In escalating hostilities stage, Muhammadiyah must be available in providing advocacy. It should investigate to find out fact and data relating to abuse, violence and harassment. After that, it issues those finding through the media it works with. It would invite international leaders and communities to assist in conflict resolution. Meanwhile, Muhammadiyah mediate leaders to engage peace negotiation. Lastly, Muhammadiyah has also role in empowering people to transform the attitudes in order to reduce tension 
and more terrible conflict.

To implement conflict resolution as noted by Nesbitt, Muhammadiyah in particular and other NGOs in general faces a number of challenges as follows:

1. Conflict prevention is no longer effective because of short-term and reactive approach than proactive. It also emphasize on post-conflict effect rather than roots of conflict.

2. Lack of coordination and cooperation between NGOs and government or among NGOs itself is a reason why conflict prevention is fragile.

3. NGOs have insufficient capacity and capability in conflict resolution. In term of conflict resolution, NGOs have been fragmented partially in its core competence and focused partially on the problem relating to the competence. ${ }^{31}$

To answer those challenges, Muhammadiyah should transform and strengthen its capability as practitioner in conflict resolution. Transformation means a changing process from weakness to the capacity for creating a strategic and effective action.Improving Muhammadiyah's capacity is important thing to equip it in regional conflict resolution. Additionally, Muhammadiyah also needs to enhance its international cooperation, research and network ${ }^{32}$. Capacity building of civil society is one of proposals issued by the participants representing civil society from ten ASEAN countries at the ASEAN Civil Society Conference to the $11^{\text {th }}$ ASEAN Summit. They propose the state to help civil society in building capacity to address regional issue. In this respect, the following suggestion is that

"Civil society wishes to state its willingness to work towards strengthening of civil society organizations in countries where there is such a need. Civil society for its part also realizes that itmust act in concert, with courage and integrity, and ensureit does not become a rubber stamp for any predetermined decisions. At the same time, civil society appreciates the importance of adopting a balanced, rational and principled approach to challenges confronting ASEAN $^{33}$.
What Muhammadiyah has done to reduce the conflict is that it initially creates an international interfaith-dialog forum namely World Peace Forum and invites the religious leaders worldwide to discuss a resolution for the religious-based conflict. This forum is necessary to extend with the number of expertise and the conflict resolution practitioner as well as the world and community leaders to prevent various conflicts in the world in general and Southeast Asia in particular.

\section{CONCLUSION}

To summarize this paper, the Islamic civil society of Indonesia namely Muhammadiyah is that the prominent Islamic movement, established in 1912, has important role in religious reform, social and cultural changing and encouraging political dynamics. As a non-state actor, Muhammadiyah has also responsibility to take part in conflict resolution occurring in Southeast Asia. Development of Muhammadiyahs' membership, institution and network lead Muhammadiyah toincrease its level from middle NGOs to the International NGOs.

International Non-governmental Organizations (INGOs), as written by Becky Nesbitt,involve in three kinds of conflict: latent conflict, escalating hostilities and peace building by implementing advocacy and people empowerment. The main problem of Muhammadiyah to do so is lack of capacity. To solve this, Muhammadiyah needs to transform itself and elevate cooperation, research and network with international community and institution. In addition, the state should pay more attention and concern on the capacity building for NGOs. Therefore, in term of Malaysia-Indonesia relationship and conflict, Muhammadiyah should contribute to be an agent of peace.

\section{CATATAN AKHIR}

Faustinus Andrea, "Pertemuan Menlu ASEAN ke-34 dan Stabilitas Kawasan Asia Tenggara" in Analisis CSIS Journal XXX/21 No 3/ 2001, p 363.

Ibid. page 365.

Banyu Agung Perwita and Yanyan Mochammad Yani, Pengantar 
IImu Hubungan International (Bandung: PT. Remaja Rosadkarya, 2006), p 11

4 Boundaries are divided into four parts: 1) Natural separators as in the case of rivers and mountain. 2) Cultural differences, such as the communal distinction that served as the basis for drawing the boundaries between India and Pakistan. 3) Historical and political considerations, as in the case of many of the African states, whose boundaries were originally drawn by European colonial powers; and 4) those established by military equilibrium, as between Israel and her Arab neighbors, or between North and South Korea. See: Jack C Plano and Roy Olton The International Relations Dictionary (Michigan: Western Michigan University, 1969), p 1

5 Anak Agung Banyu Perwita, "The Impact of Territorial Border Problems on Indonesia's Security", The Indonesian Quaterly Journal. Vol.34 No.3/2006, p.203.

6 Ibid. p. 202.

7 Sita Bali, "Migration and Refugees" in Issues in World Politics edited by Brian White, Richard Little and Michael Smith (2001). (New York: Palgrave, 2001) p. 178.

8 National productivity of host country is an advantage of migrant worker. At the same time, the sending country like Indonesia has benefit from its migrant workers: 1) Decreasing the unemployment problem. 2) Declining the demand for consumption and facilities. See Bali Sita,. Op cit. 180.

9 Jhon B Sijanto, Ganyang Malaysia, Politik Konfrontasi Bung Karno. (Yogyakarta: InterpreBook, 2010), p. 29

10 Ibid. p. 30

11 Syafaruddin Usman and Din Isnawita, Ancaman Negeri Jiran: Dari "Ganyang Malaysia" sampai Konflik Ambalat (Yogyakarta: MedPress, 2009), p. 32-33

12 Fadilla, Ramadhian, "Pak Harto, Untold Story", (http://www.tribunnews.com/2011/06/14/kampong-soehartobukti-hubungan-baik-indonesia-malaysia). See also: (www.detik.com/read/2011/06/08/121412/1655724/10/hubunganindonesia-malaysia-gemilang-di-era-soeharto)

13 Wawan H. Purwanto, Panas Dingin Hubuangan Indonesia-Malaysia (Jakarta: CMB Press, 2010), p. 16-18

14 Rochdi Mohan Nazala, "Malaysia-Indonesia Relationships and the Future of Southeast Asia Stability", Multiversa Vol. I No. 2/10/ 2010, p. 219

15 Affan Ghafar, Politik Indonesia, Transisi Menuju Demokrasi (Yogyakarta: Pustaka Pelajar, 1999), p. 178

16 Julliete Van Wassenhove, "Civil Society, Religious Affiliation and Political Participation East Asia", ICAS News. Singapore 19-22 August 2003

17 Jhon W, Meyer, Gilli S. Drori and Hokyu Hwang, "World Society and the Proliferation of Formal Organization" in Globalization and Organization, World Society and Organizational Change, (Oxford University Press: New York, 2006), p. 25

18 Oussama Safa, Conflict Resolution and Reconciliation in the Arab World, The Work of Civil Society Organizations in Lebanon and Morocco, www. berghof-handbook.net, p. 3

19 Bernard Mayer, The Dynamics of Conflict Resolution; A Practitioner's Guide (San Francisco: Jossey-Bass. Inc Publisher, 2000), p. 3

20 Bernard Mayer, Op.Cit. p. 4
21 Ibid. p. 5

22 Bernard Mayer, Op.Cit. p. 12-14.

23 Surwandono, Resolusi Konflik Dunia Islam (manuscript), p. 11

24 Becky Nesbitt, The Role of NGOs in Conflict Resolutionin Africa: an Institutional Analysis paper presented at the Institutional Analysis and Development Mini-Conference, May 3rd and 5th, 2003, Workshop in Political Theory and Policy Analysis, Indiana University, Bloomington, Indiana, USA, p. 2.

25 Ibid. p. 5

26 Becky Nesbitt, Op.Cit, p. 6-7

27 Ibid., p. 14-15

28 Javanese people living in Yogyakarta where Muhammadiyah was established is illustrated by Sutiyono as a cow eating all vegetables at the day and then bringing it back into the mouth at the night. It means that Javanese people might swallow all imported cultures and religious teaching. After that, they adjust it to their own culture.

\section{REFERENCES}

\section{BOOKS}

Alfian. 1989, Politik Kaum Modernitas; Perlawanan Muhammadiyah terhadap Kolinalisme Belanda, Gadjah Mada University Press, Yogyakarta

Bali, Sita, "Migration and Refugees" in Issues in World Politics edited by Brian White, Richard Little and Michael Smith. 2001, Palgrave, New York

Center for Security and Peace Studies (CSPS) of Universitas Gadjah Mada. 2006, Masyarakat Sipil dan Pencegahan Konflik Bersenjata (Hasil Lokakarya di Solo 1-2 Desember 2005), CSPS Book, Yogyakarta

Ghafar, Affan. 1999, Politik Indonesia, Transisi Menuju Demokrasi,Pustaka Pelajar, Yogyakarta

Mayer, Bernard. 2000, The Dynamics of Conflict Resolution; A Practitioner's Guide Jossey-Bass. Inc Publisher, San Fransisco

Meyer, Jhon W, Drori, Gilli S. and Hwang, Hokyu. 2006, "World Society and the Proliferation of Formal Organization" in Globalization and Organization, World Society and Organizational Change, Oxford University Press, New York

Perwita, Anak Agung Banyu Perwita and Yani, Yanyan Mochammad. 2006, Pengantar Ilmu Hubungan International, PT. Remaja Rosadkarya, Bandung

Plano, Jack C and Olton, Roy. 1969, The International Relations Dictionary, Western Michigan University, Michigan

Purwanto, Wawan H. 2010, Panas Dingin Hubuangan IndonesiaMalaysia, CMB Press, Jakarta

Sijanto, Jhon B. 2010, Ganyang Malaysia, Politik Konfrontasi Bung Karno, InterpreBook, Yogyakarta

Surwandono, Resolusi Konflik Dunia Islam (manuscript)

Sutiyono. 2010, Benturan Budaya Islam: Puritan dan Sinkretis, Kompas, Jakarta

Usman, Syafaruddin Usman and Isnawita, Din. 2009, Ancaman Negeri Jiran: Dari "Ganyang Malaysia" sampai Konflik Ambalat, MedPress, Yogyakarta 


\section{WEBSITE, NEWS AND DOCUMENT}

http://www.detik.com/read/2011/06/08/121412/1655724/10/

hubungan-indonesia-malaysia-gemilang-di-era-soeharto

Document of Statement of The ASEAN Civil Society Conference To

The $11^{\text {th }}$ ASEAN Summit

http://www.tribunnews.com/2011/06/14/kampoeng-soeharto-buktihubungan-baik-indonesia-malaysia

\section{JOURNALS}

Andrea, Faustinus "Pertemuan Menlu ASEAN ke-34 dan Stabilitas Kawasan Asia Tenggara" in Analisis CSIS Journal XXX/21 No 3/2001 Becky Nesbitt, The Role of NGOs in Conflict Resolutionin Africa: an Institutional Analysis paper presented at the Institutional Analysis and Development Mini-Conference, May 3rd and 5th, 2003,

Workshop in Political Theory and Policy Analysis, Indiana University, Bloomington, Indiana

Nazala, Rochdi Mohan, "Malaysia-Indonesia Relationships and the Future of Southeast Asia Stability", Multiversa Vol. I No. 2/10/2010 Perwita, Anak Agung, Banyu, "The Impact of Territorial Border Problems on Indonesia's Security", The Indonesian Quaterly Journal. Vol.34 No.3/2006

Safa, Oussama Conflict Resolution and Reconciliation in the Arab World, The Work of Civil Society Organizations in Lebanon and Morocco, www.berghof-handbook.net

Wassenove, Julliete Van, "Civil Society, Religious Affiliation and Political Participation East Asia", ICAS News. Singapore 19-22 August 2003 